\title{
OPEN Terrestrial snail-mucus mediated green synthesis of silver nanoparticles and in vitro investigations on their antimicrobial and anticancer activities
}

Pramod C. Mane ${ }^{1}$, Shabnam A. R. Sayyed ${ }^{1}$, Deepali D. Kadam ${ }^{1}$, Manish D. Shinde ${ }^{2}$, Amanullah Fatehmulla ${ }^{3}$, Abdullah M. Aldhafiri ${ }^{3 凶}$, Eman A. Alghamdi $^{3}$, Dinesh P. Amalnerkar ${ }^{4 \bowtie}$ \& Ravindra D. Chaudhari ${ }^{1 \bowtie}$

Over the past few years, biogenic methods for designing silver nanocomposites are in limelight due to their ability to generate semi-healthcare and para-pharmaceutical consumer goods. The present study reports the eco-friendly synthesis of silver nanoparticles from the hitherto unexplored mucus of territorial snail Achatina fulica by the facile, clean and easily scalable method. The detailed characterization of the resultant samples by UV-Visible Spectroscopy, FESEM-EDS, XRD and FTIR Spectroscopy techniques corroborated the formation of silver nanoparticles in snail mucus matrix. The resultant samples were tested against a broad range of Gram positive and Gram negative bacteria like Escherichia coli, Staphylococcus aureus, Klebsiella pneumoniae, Pseudomonas aeruginosa and a fungal strain Aspergillus fumigatus by well diffusion method. The results indicate that silver nanoparticles in mucus matrix exhibit strong antibacterial as well as antifungal activity. The pertinent experiments were also performed to determine the inhibitory concentration against both bacterial and fungal strains. Anticancer activity was executed by in vitro method using cervical cancer cell lines. Curiously, our biogenically synthesized Ag nanoparticles in biocompatible mucus revealed anticancer activity and demonstrated more than $15 \%$ inhibition of Hela cells. We suggest an interesting possibility of formulating antimicrobial and possibly anticancer creams/gels for topical applications in skin ailments.

Owing to their intrinsic antimicrobial properties, nanoparticles of oligodynamic noble metals (viz., gold and silver) are on the verge of making unique niche in the fast-moving semi-healthcare and para-pharmaceutical consumer goods such as shampoos, detergents, soaps, cosmetic products, tooth-pastes etc ${ }^{1}$. The customary chemical and physical methods of generating such nano-metallic particles suffer from disadvantages like low yield, high energy consumption, high capital investment, contamination due to solvents, lack of uniform distribution and hindrance due to synthetic additives, capping agents or stabilizing media especially while exhibiting antimicrobial effect ${ }^{2}$. Consequently, sustained efforts are being made to develop clean, green and eco-friendly processes for synthesizing metallic nanoparticles in industrially viable setting. In this context, micro-organisms and plant-mediated biogenic synthesis of metallic nanoparticles appeared to gain immense popularity. The major advantage of using biological materials is the availability of secondary metabolites, amino acids, proteins which are routinely used in the synthetic steps of nanoparticles ${ }^{3,4}$. In fact, microorganisms such as bacteria, fungi, actinomycetes and yeasts have been reported to possess inherent potential to generate nanoparticles either by

${ }^{1}$ P. G. Department of Zoology and Research Centre, Shri Shiv Chhatrapati College of Arts, Commerce and Science, Junnar, Pune 410 502, India. ${ }^{2}$ Centre for Materials for Electronics Technology, Panchawati, Off-Pashan Road, Pune 411008, India. ${ }^{3}$ Department of Physics and Astronomy College of Science, King Saud University, P. O. Box 2455, Riyadh 11451, Saudi Arabia. ${ }^{4}$ Department of Technology, Savitribai Phule Pune University, Pune 411 008, India. ${ }^{\varpi}$ email: adhafiri@ksu.edu.sa; dpa54@yahoo.co.in; rdchaudhari2004@yahoo.co.in 
intra or extra cellular process and are considered as potential micro-factories for nanoparticles generation ${ }^{1}$. On the other hand, plant-mediated phytogenic synthesis of nanoparticles is rapid, cost-effective, easily scalable to bulk-production and free from complex and multiple processing steps like microbial isolation, culturing and maintenance etc. Additionally, specific medicinal properties of certain plants used in phytogenic synthesis can be synergistically beneficial in the therapeutic applications of the resultant nanoparticulate biocomposites. However, biogenic methodologies hitherto reported for the synthesis of nanoparticles are mainly confined to only micro-organisms and plant extracts and use of external bodily secretions of live animals has been hardly reported in eco-friendly biogenic synthesis of metallic nanoparticles involving reduction and stabilization steps ${ }^{5}$. Due to indiscriminate and uncontrolled use of many plant species, the biodiversity is extremely hampered, as many plant species are now on the verge of extinction from the nature. Use of live organisms to obtain their body secretions is far more advantageous over the use of plants, as the organism is not sacrificed and safely returned to the nature thus resulting in biodiversity conservation as well. In the present endeavor, we explored snail mucus externally secreted by Achatina fulica in the biogenic synthesis of silver nanoparticles.

Achatina fulica is a terrestrial snail, belonging to phylum Mollusca, having a status of "serious agricultural pest" in India. It secretes a sticky, complex, viscous secretion through specialized goblet cells in the columnar epithelium. The mucus serves various functions such as lubrication for the passage of objects, maintains hydrated layer on the epithelium, blocks the pathogens etc. throughout the life cycle of A. fulica ${ }^{6}$. Snail mucus is mainly a mixture of glycoproteins, hyaluronic acid and glycolic acid, all of which have long-documented benefits for the skin. The gel like nature of mucus is due to the presence of glycoproteins ${ }^{7}$. Hyaluronic acid in the mucus has moisturizing properties while glycolic acid helps to stimulate collagen responsible for skin-glow and radiant complexion. On account of all such features, snail mucus is an important ingredient of several cosmetic and para-pharmaceutical products ${ }^{8}$. Aside from such cosmetic aspects, it is felt that main ingredients of snail mucus (proteins, amino acids etc.) can contribute/help assist in bio-reduction and bio-stabilization/surface functionalization steps involved in metallic nanoparticles synthesis.

Amongst oligodynamic noble metals, silver nanoparticles find notable applications in molecular diagnostics, in antimicrobial and anti-inflammatory therapies, as well as in devices that are used in several medical procedures ${ }^{9,10}$. Nosocomial infections as well as community-acquired infections caused by multidrug-resistant (MDR) pathogens are recognized as one of the most serious threats in public health settings. To tackle the problem of MDR diseases, novel strategies are being continuously evolved for the drug development with focus on long-term and effective therapies ${ }^{11}$. In this context, it may be noted that the nanomaterial-based drug development approaches cannot exert evolutionary pressure on bacteria and hence can be beneficial in combating MDR if biocompatibility and cytotoxicity issues are addressed aptly ${ }^{12}$. Interestingly, in our previous study, it was observed that the biologically synthesized silver nanocomposites do not exhibit toxicity against non-target organisms ${ }^{13}$. Silver nanoparticles are also used in water filters to kill the pathogenic micro-organisms which cause water borne diseases such as diarrhea ${ }^{14,15}$. In addition to promising antimicrobial potential, nanoparticles have demonstrated effective action against malarial parasites ${ }^{16-19}$.

By bearing in mind the salient aspects of hitherto unexplored snail mucus as novel biomaterial and taking into account the antimicrobial merits of silver nanoparticles, we have carried out the present biogenic synthesis of silver nanoparticles in snail mucus matrix. Besides antimicrobial investigations; we have also performed preliminary in vitro investigations on the anticancer activity of the resultant bio-nanocomposite. It is believed that our research outcomes can add new insights into the science of organic-inorganic hybrid nanomaterials based emergent drug formulations.

\section{Results and discussion}

Protein estimation. The mucus was collected and estimation of protein and amino acid contents was performed. The results revealed that the mucus contains $0.463 \mu \mathrm{g} / \mathrm{ml}$ of proteins and $200 \mu \mathrm{g} / \mathrm{ml}$ of free amino acids. To determine the electrophoretic profile of the mucus, it was subjected to SDS - PAGE. The patterns of mucus proteins were verified by the bands clearly seen on the gel. It was observed that the mucus contains proteins of molecular weights 3.5, 14.3, 20.1, 29.0, 43.0, 66.0 and $97.4 \mathrm{kDa}$ (Fig. 1).

Many animals including invertebrates secrete mucus which contains lectins, lysozymes, immunoglobulin, $\mathrm{C}$ - reactive proteins, antimicrobial peptides, proteins etc. which are mainly related to immune factors ${ }^{20}$. The proteins present in mucus are involved in immune and stress responses ${ }^{21}$. The mucus is watery, thin fluid containing total soluble proteins, carbohydrates, lipids, amino acids etc ${ }^{22}$. The mucus of Actinia equina contains around $24.2 \%$ of proteins. The electrophoretic analysis of $A$. equine exhibited fourteen major protein bands, ranging from 12 to $200 \mathrm{kDa}^{23}$. Many researchers recorded proteins from fishes as well. It was also noted that the bands of Mastacembelus armatus mucus were observed at $34 \mathrm{kDa}, 45 \mathrm{kDa}$ and $144 \mathrm{kDa}^{24,25}$. The present study confirms that the A. fulica mucus contains proteins of molecular weights 3.5, 14.3, 20.1, 29.0, 43.0, 66.0 and $97.4 \mathrm{kDa}$. It was also observed that crude purified extracts from common garden snail, Helix aspersa muller mucus (Helix Complex) can actively encourage cell migration, wound healing process, skin protection and antimicrobial activity ${ }^{8,26}$. The snail mucus and $5 \%$ chitosan can be used for galenic preparations of anti-inflammatory creams which could be effectively applied for wound healing ${ }^{27}$.

Thus, mucus of A. fulica, which is rich in different proteins and amino acids, was used in this study for different purposes including synthesis of silver nanoparticles and assessing their antimicrobial and anticancer performance in the composite form (Fig. 2).

UV-Visible Spectroscopy of $\boldsymbol{A}$. fulica mucus and AgNPs-SM samples. The A. fulica mucus and silver nanoparticles synthesized in A. fulica mucus matrix were studied for their optical properties. The UVVisible spectra recorded for A. fulica mucus and AgNPs-SM samples are displayed in Fig. 3a,b. It is noted that 


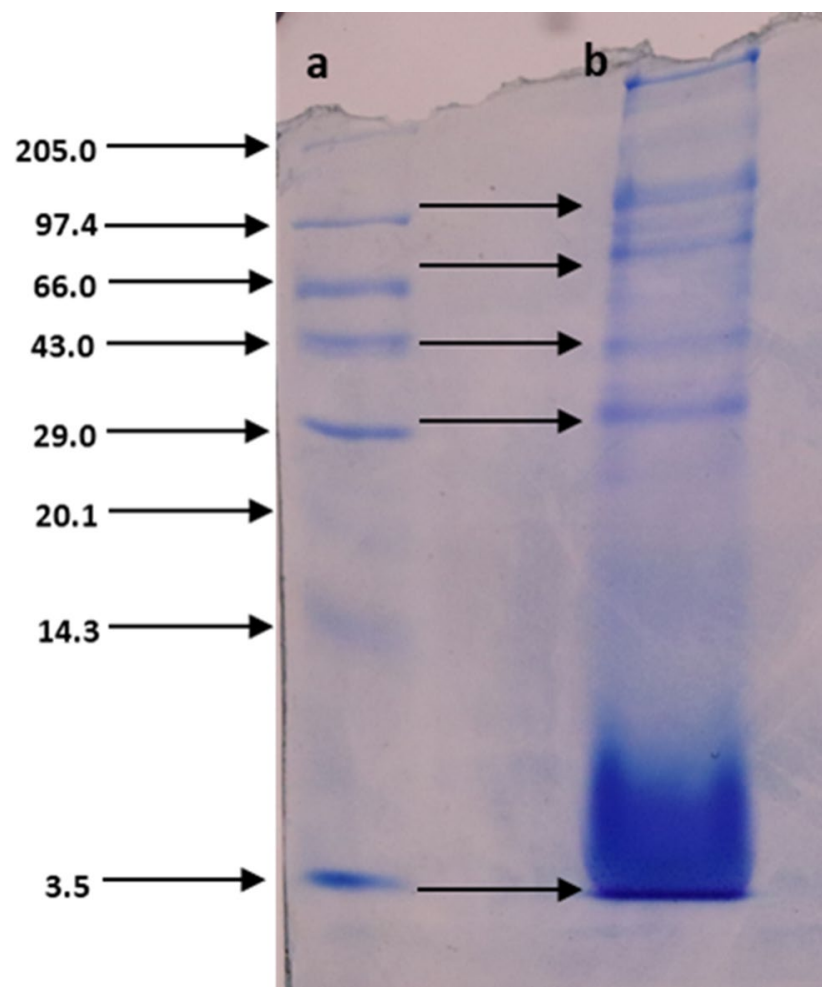

Figure 1. Electrophoretic pattern of mucus (a) standard protein marker, (b) proteins of A. fulica mucus. (Fulllength image of the gel is presented in Supplementary Fig. S1).
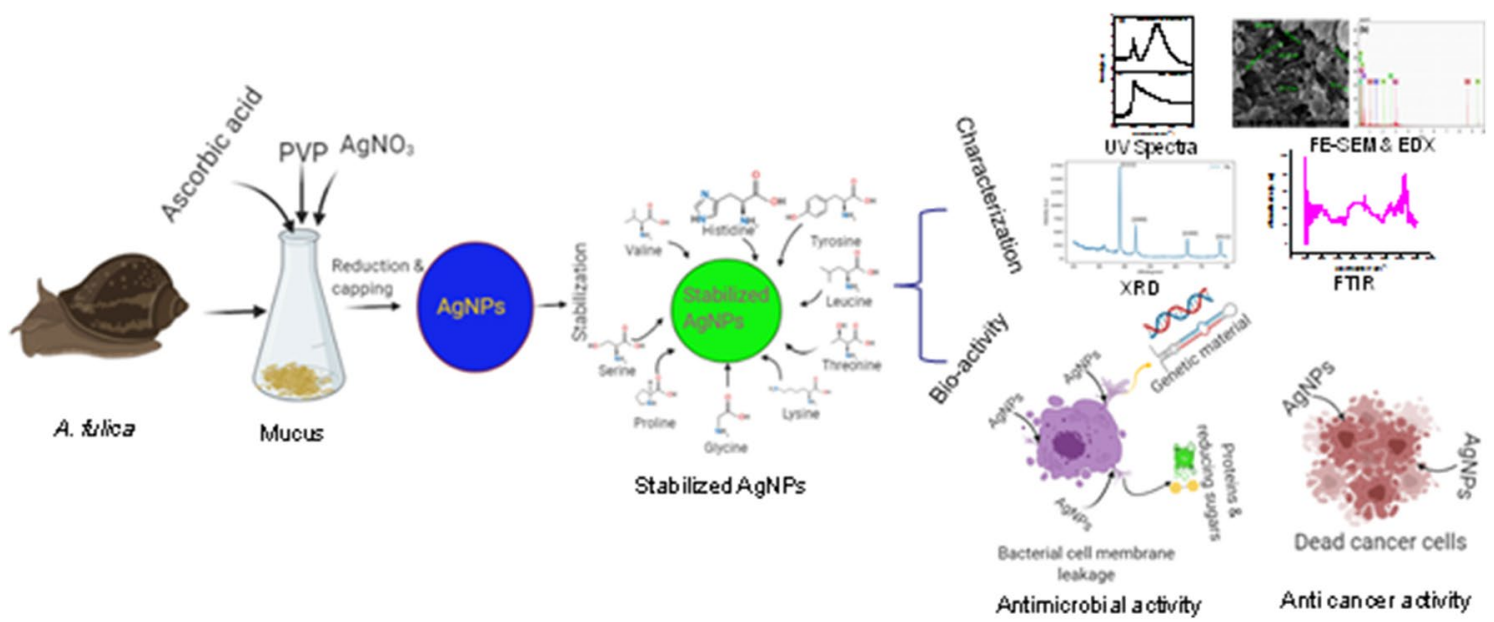

$\overrightarrow{F T R}$

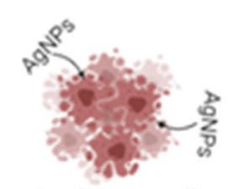

Dead cancer cells

Antimicrobial acturit

Anticancer adivity

Figure 2. Schematic representation for the generation of silver nanoparticles in snail mucus from $A$. fulica and bioactivity of the resultant bionanocomposite (AgNPs-SM).

the snail mucus exhibits maximum absorption at $293 \mathrm{~nm}$ (Fig. 3a); while the composite spectrum of AgNPsSM sample (Fig. 3 b) reveals (i) contribution from snail mucus with absorption peak centered at $293 \mathrm{~nm}$ and (ii) relatively sharp absorption peak centered at $420 \mathrm{~nm}$ attributable to characteristic Surface Plasmon Resonance (SPR) phenomenon reported for spherical silver nanoparticles ${ }^{13}$. The noticeable contribution from snail mucus and presence of relatively sharp characteristic SPR peak in the spectrum evidently suggests key role of mucus as bio-stabilizing medium in controlling the spontaneous aggregation of Ag nanoparticles. Furthermore, we have observed for any visual change in color for various dispersion admixtures of the individual reactants viz., (a) PVP-silver nitrate, (b) ascorbic acid-silver nitrate, (c) PVP-ascorbic acid-silver nitrate and (d) snail mucus-PVP-ascorbic acid and also recorded their UV-Visible spectra (See Supplementary Fig. S2 and Supplementary Fig. S3 a, b, c \& d). From such study, we could observe only one absorption peak around $295 \mathrm{~nm}$ for all the four admixtures. This observed absorption peak for all the admixtures incidentally matches with that of snail-mucus and might be due to either dominant contribution of the individual reactants in the admixtures or 


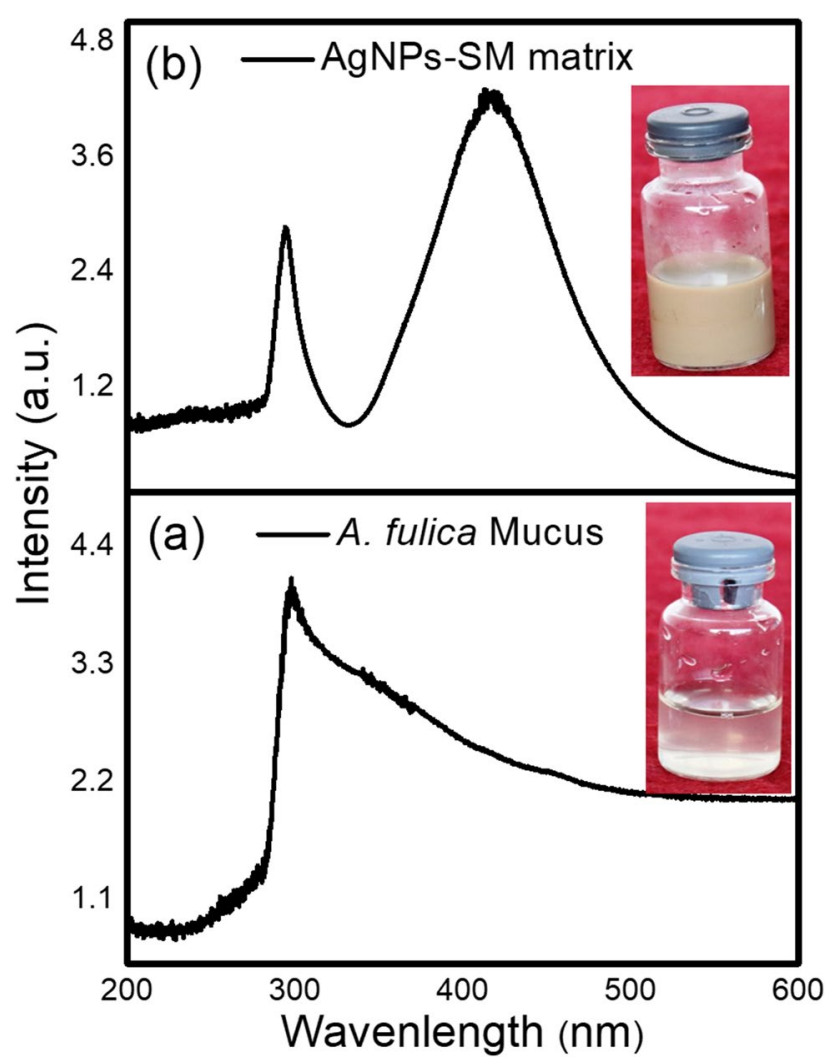

Figure 3. UV-Visible spectra of (a) A. fulica mucus (b) Silver nanoparticles in snail mucus matrix (AgNPs-SM).
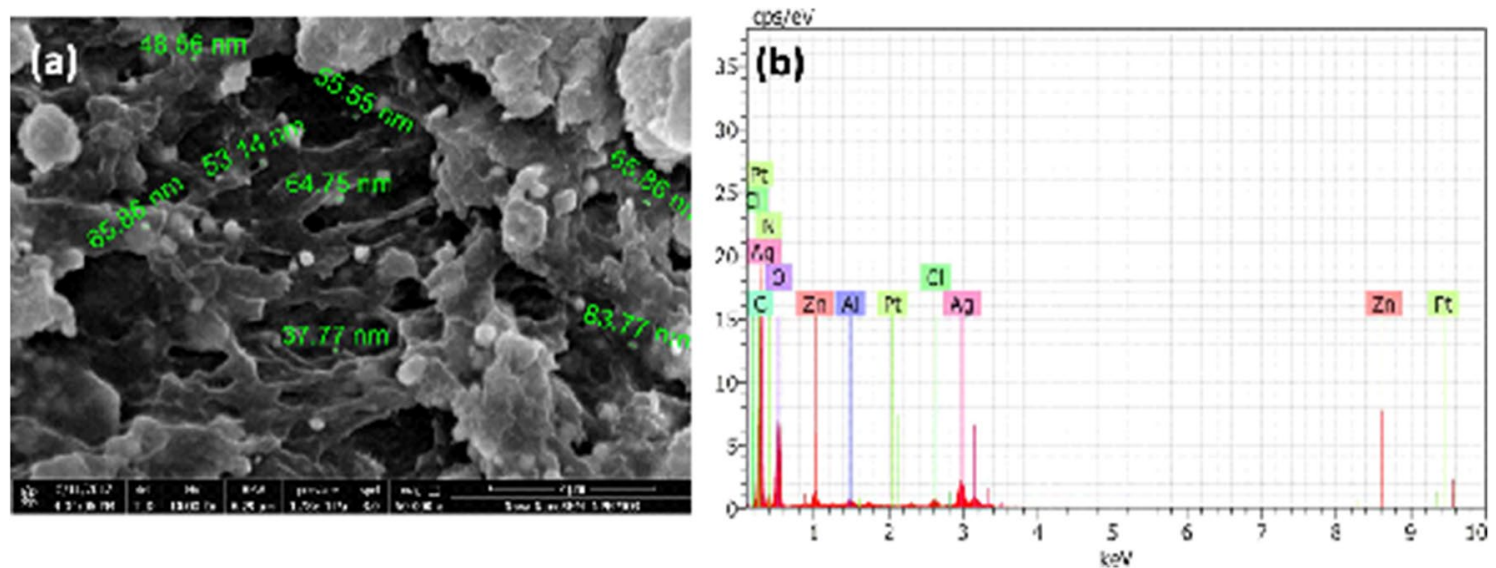

Figure 4. (a) FESEM image and (b) EDS spectrum of silver nanoparticles synthesized using A. fulica mucus.

overlapping influence of the maximum absorption peaks of PVP and ascorbic acid around $320 \mathrm{~nm}$ and $265 \mathrm{~nm}$, respectively ${ }^{28-29}$. Besides bio-stabilization, snail-mucus contents especially amino acids can facilitate the controlled reduction of silver nitrate to nanoscale silver particles as illustrated in Fig. 2.

The UV spectral analysis of A. fulica mucus shows a sharp peak between $200-300 \mathrm{~nm}$. It was reported that the fish mucus exhibits more than one peak in spectral analysis ${ }^{30}$. The absorbance of all types of mucus was around $290 \mathrm{~nm}$ which can be ascribed to the presence of nucleic acid and proteins in mucus ${ }^{31}$.

FESEM with EDS analysis of AgNPs-SM Sample. Figure 4a,b displays FESEM image and EDS spectrum of silver nanoparticles formed in A. fulica mucus matrix. Polydispersed and broadly spherical silver nanoparticles exhibiting size in the range of $37 \mathrm{~nm}-87 \mathrm{~nm}$ were observed on the surface as well as the interior side of biological matrix of A. fulica. Thus, FESEM image hints at bio-stabilization of Ag nanoparticles in A. fulica mucus matrix in composite form. The pertinent EDS spectrum (Fig. 4b) mainly discloses the presence of silver 


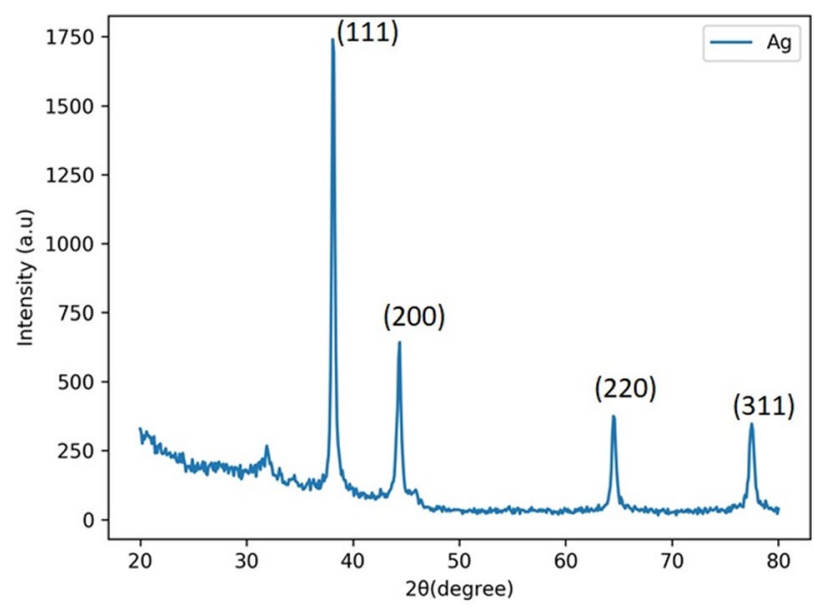

Figure 5. X-ray diffractogram of silver nanoparticles synthesized within A. fulica mucus matrix.

with other elements namely, zinc, oxygen and chlorine, usually found in typical biological synthesis protocols ${ }^{32}$. Conspicuous absence of calcium is a noteworthy factor in the present analysis.

XRD Analysis of AgNPs-SM. Typical X-ray diffractogram of the silver nanoparticles synthesized in $A$. fulica mucus is presented in Fig. 5. It confirms formation of cubic ( $\mathrm{fcc}$ ) silver as evidenced by XRD peaks corresponding to (111), (200), (220) and (311) planes which match well with JCPDS card no. 04-0783 for the cubic silver.

FTIR Spectroscopic Analysis of AgNPs-SM. FTIR spectral analysis of the typical AgNPs-SM sample was carried out in the range of $400-4000 \mathrm{~cm}^{-1}$ (Fig. 6a). The spectral analysis in the narrow range of $800 \mathrm{~cm}^{-1}$ to $2200 \mathrm{~cm}^{-1}$ is given in Fig. 6b. In this region, the spectral profile indicates the presence of a protein component with $\beta$-sheeting and $\beta$-turns that are ascribable to the band characteristics of Amide II $\left(1543 \mathrm{~cm}^{-1}\right)^{33}$. The band due to Amide I $\left(1643 \mathrm{~cm}^{-1}\right)$ is suspiciously absent. Additionally, numerous bands in the region between 900 $\mathrm{cm}^{-1}$ and $1450 \mathrm{~cm}^{-1}$ have been noted which stand for a combination of bands implying the presence of ionised and unionised carboxylic acid, $\mathrm{CH}_{2}, \mathrm{CH}_{3}$ and $-\mathrm{OH}$ as well as secondary amide echoes ${ }^{26}$. Ester bonds observed in some sugars are seen in the form of bands at $1736 \mathrm{~cm}^{-1}$ and $1230 \mathrm{~cm}^{-1}$. The spectrum obtained in the range of $2700 \mathrm{~cm}^{-1}$ to $3700 \mathrm{~cm}^{-1}$ (Fig. $6 \mathrm{c}$ ) revealed the higher wavenumber bands attributable to the presence of $\mathrm{CH}_{2}$ around $2855 \mathrm{~cm}^{-1}$ and $2925 \mathrm{~cm}^{-1}$ probably from a lipid component in the mucus, while $\mathrm{CH}_{3}$ echoes $\left(2955 \mathrm{~cm}^{-1}\right.$ and $\left.2974 \mathrm{~cm}^{-1}\right)$ were also noted. These components are also manifested at lower wavenumbers $\left(1320 \mathrm{~cm}^{-1}\right.$, Fig. 6b). The bands observed in the range of $2800 \mathrm{~cm}^{-1}$ and $3000 \mathrm{~cm}^{-1}$ possibly signify aromatic echoes in addition to exhibiting the presence of bonded $\mathrm{OH}$ within the $\mathrm{COOH}$ moiety (Fig. 6c). The signal relating to bonded $\mathrm{OH}$ was specifically detected at $3515 \mathrm{~cm}^{-1}$ and this feature may be due to the presence of sugar side-chains rather than the protein core. Benzene overtones occurring at the low wave numbers $\left(1800 \mathrm{~cm}^{-1}\right.$ to $\left.2000 \mathrm{~cm}^{-1}\right)$ are also not found.

Antimicrobial activity. Our biogenically synthesized silver nanoparticulate composites (AgNPs-SM) were assessed for the antimicrobial assay against the Gram negative and Gram positive bacterial strains.

The antibacterial activity of the dispersed biogenic silver nanoparticles was verified by observing a clear zone of inhibition (ZI). No zone of inhibition was found in the vehicle control well which suggests that the antimicrobial activity was specifically due to the silver nanoparticles stabilized in mucus matrix. All the selected bacterial strains displayed a noticeable zone of inhibition (Fig. 7). In this study, we also compared the antimicrobial performance of the resultant Ag nanoparticles in mucus matrix with that of standard antibiotic ciprofloxacin. Besides, we have checked the antimicrobial activity of the powdered products formed through the combinative admixtures of individual reactants viz., (a) PVP-ascorbic acid- silver nitrate and (b) ascorbic acid-silver nitrate as controls to highlight the contribution of Ag nanoparticles generated in snail mucus matrix. We could not observe an appreciable antimicrobial activity in case of these products (See Supplementary Fig. S4 a and b). Since remaining admixtures of snail mucus-PVP-ascorbic acid and PVP-silver nitrate did not disclose apparent formation of any powder product, their antimicrobial activity was not carried out. Overall, it has been observed that silver nanoparticles-mucus matrix based nanocomposite dispersion exhibits better antimicrobial activity against Staphylococcus aureus (ZI : $16 \pm 1.78 \mathrm{~mm}$ ), Pseudomonas aeruginosa (ZI : $15 \pm 2.68 \mathrm{~mm}$ ) and slightly less against Klebsiella pneumoniae (ZI : $14 \pm 1.78 \mathrm{~mm}$ ), Escherichia coli (ZI : $14 \pm 2.68 \mathrm{~mm}$ ) and Aspergillus fumigatus $(\mathrm{ZI}: 15 \pm 0.89 \mathrm{~mm})$ at $75 \mu \mathrm{g}$ concentration of nanoparticles.

Minimum Inhibitory Concentration (MIC), Minimum Bactericidal Concentration (MBC) and Minimum Fungicidal Concentration (MFC) of silver nanoparticles in snail-mucus matrix. After 

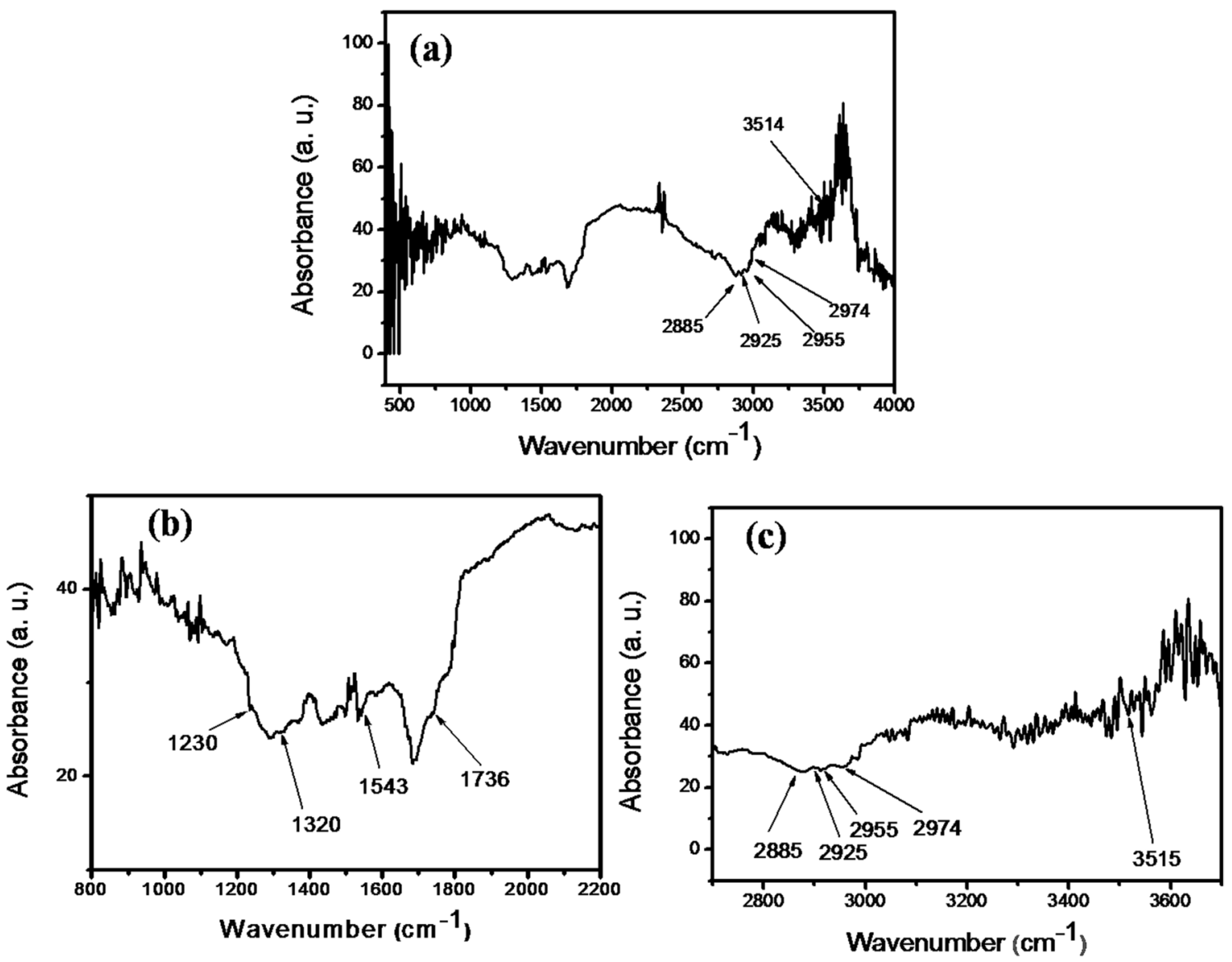

Figure 6. FTIR spectra of AgNPs-SM sample recorded at different spectral regions-(a) $400-4000 \mathrm{~cm}^{-1}$, (b) $800-2200 \mathrm{~cm}^{-1}$ and (c) $2700-3700 \mathrm{~cm}^{-1}$.

confirming antimicrobial activity of biogenically synthesized silver nanoparticles through agar well diffusion assay, values of MIC, MBC and MFC were determined for all the selected micro-organisms. The typical experiments were conducted by using $10^{6} \mathrm{CFU} / \mathrm{ml}$ of microbial concentrations and various concentrations of silver nanoparticles $(2,2.5,3,3.5,4$ and $4.5 \mu \mathrm{g} / \mathrm{ml})$. It was observed that, after completion of the incubation period, visual growth of K. pneumoniae, E. coli, P. aeruginosa, S. aureus and A. fumigatus was not perceived when supplemented with $3.5,3.5,4.0,3.0$ and $2.0 \mu \mathrm{g} / \mathrm{ml}$ of silver nanoparticles, respectively (Fig. 8). The corresponding MBC and MFC values are summarized in Table 1.

To overcome the problem of antibiotic resistance in bacteria, use of silver nanoparticles seems to be a good alternative to the present generation antibiotics. The present study explored silver nanoparticles-mucus matrix based bionanocomposite for antimicrobial activity against four bacterial strains and one fungal strain. It is worthwhile to mention that, amongst other nanoparticles, silver nanoparticles had strongest antibacterial activities against several pathogenic bacteria ${ }^{34}$. Herein, the antimicrobial activity of silver nanoparticles-mucus matrix based bionanocomposite is compared with standard antibiotic i.e. Ciprofloxacin/ Clotrimazole. The result of this study indicated that silver nanoparticles-mucus matrix based bionanocomposite exhibited slightly more antimicrobial activity than Ciprofloxacin/ Clotrimazole as shown in Table 1.

In literature, numerous reports are available on green synthesis of metallic nanoparticles by using various biological sources including fungi, bacteria, plants etc. and elucidating their functional superiorities over metallic nanoparticles generated by traditional chemical and physical methods ${ }^{1-5,11,35}$. In the present study, we successfully synthesized the silver nanoparticles in A. fulica mucus matrix and ascertained its potential for biological applications including antimicrobial and anti cancer activities. It may be noted that Gubitosa et al.also carried out the synthesis of gold nanoparticles by using mucus secreted by garden snails Helix aspersa Muller and used the resultant bionanocomposite for biomedical applications involving potential anti-inflammatory properties ${ }^{36}$. At this juncture, it is felt that the functional combination of (i) broad-spectrum antimicrobial silver nanoparticles and (ii) anti-inflammatory as well as skin rejuvenating ingredients of the snail-mucus in our AgNPs-SM composite can be explored in topical treatment of acne, an extremely common bacterial skin disease. In particular, snail mucus possess dermis hydrating and collagen regulating properties ${ }^{8,25,36}$ which can control formation of acne scars. Additionally, it may be recalled that acne is susceptible to develop resistance for the long-term routine antibiotic treatment which may not be ordinarily anticipated in case of metallic nanoparticles. As a whole, it may be fascinating endeavor to realize AGNPs-SM based topical cream/gel for effective acne treatment as well as for rapid wound healing without leaving scar on the affected skin. 


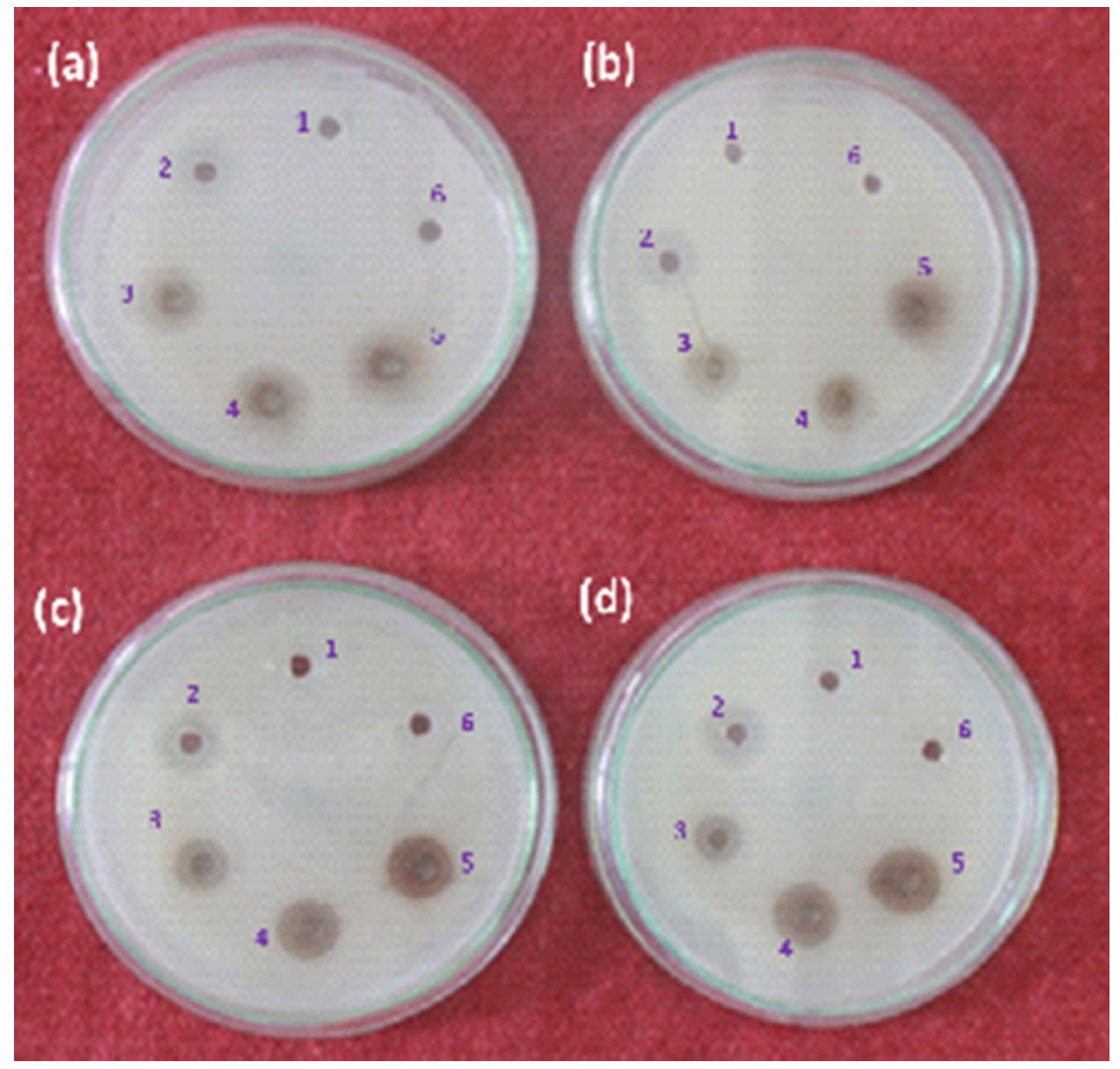

Figure 7. Antimicrobial activity of AgNPs-SM against (a) Klebsiella pneumoniae (b) Escherichia coli (c) Pseudomonas aeruginosa (d) Staphylococcus aureus. In each plate, (1) $\mathrm{AgNO}_{3}$, (2) Ciprofloxacin/ Clotrimazole, (3) $25 \mu \mathrm{g}$ of Ag NPs, (4) $50 \mu \mathrm{g}$ of Ag NPs, (5) $75 \mu \mathrm{g}$ of Ag NPs and (6) A. fulica mucus were added, respectively.
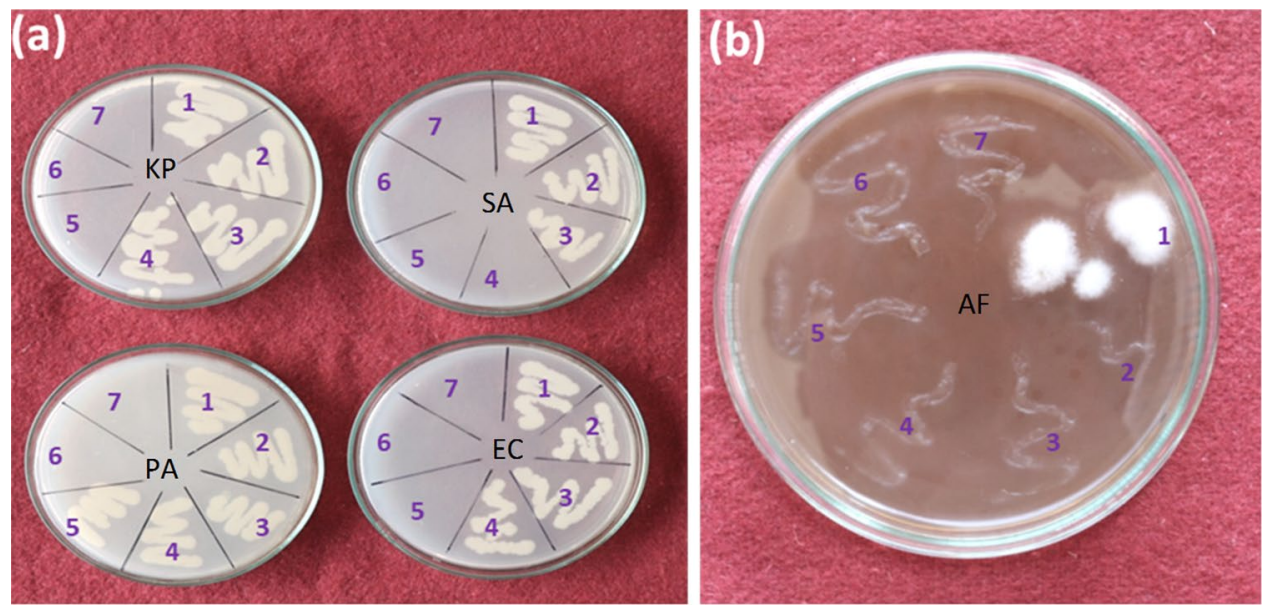

Figure 8. $\mathrm{MIC}$ and MBC/MFC of silver nanoparticles (AgNPs) synthesized in A. fulica mucus matrix. In each plate represents (1) control and AgNPs concentrations of-(2) $2 \mu \mathrm{g} / \mathrm{mL}$, (3) $2.5 \mu \mathrm{g} / \mathrm{mL}$, (4) $3 \mu \mathrm{g} / \mathrm{mL}$, (5) $3.5 \mu \mathrm{g} /$ $\mathrm{mL}$, (6) $4 \mu \mathrm{g} / \mathrm{mL}$ and (7) $4.5 \mu \mathrm{g} / \mathrm{mL}$, respectively. 


\begin{tabular}{|l|l|l|l|}
\hline \multirow{2}{*}{ Name of the microorganisms } & \multicolumn{2}{|l|}{ Zone of inhibition ( mm ) } & MBC/MFC ( $\mu \mathrm{g} / \mathrm{ml})$ \\
\cline { 2 - 5 } & AgNPs & Positive Control (Ciprofloxacin/Clotrimazole) & AgNPs \\
\hline Klebsiella pneumoniae & $14 \pm 1.78$ & $15 \pm 1.78$ & 3.5 \\
\hline Escherichia coli & $14 \pm 2.68$ & $14 \pm 1.54$ & 3.5 \\
\hline Pseudomonas aeruginosa & $15 \pm 2.68$ & $15 \pm 2.36$ & 4.0 \\
\hline Staphylococcus aureus & $16 \pm 1.78$ & $13 \pm 2.36$ & 3.0 \\
\hline Aspergillus fumigatus & $15 \pm 0.89$ & 00 & 2.0 \\
\hline
\end{tabular}

Table 1. Zone of inhibition and MIC of silver nanoparticles synthesized in A. fulica mucus matrix. All the values are mean of three replicates, \pm standard deviation.

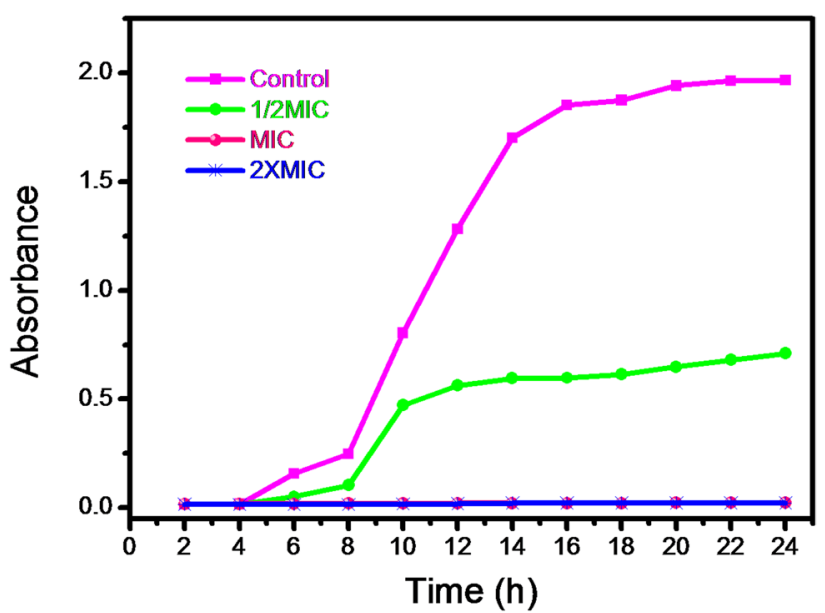

Figure 9. Time kill assay of $S$. aureus treated cells with AgNPs-SM bionanocomposites.

As compared to bacterial diseases, fungi mediated diseases are tedious to control, because currently very few antifungal drugs are available ${ }^{37}$. In view of this scenario, there is an urgent and inevitable need to formulate antifungal agents which must be cost effective, eco-friendly and most importantly biocompatible ${ }^{38}$. Literature survey indicates that, silver nanoparticles play an important role as an antifungal agent ${ }^{39}$. For example, silver nanoparticles exhibited a good antifungal activity against several fungi like Aspergillus niger, Candida albicans, Phoma glomerata, Fusarium semitectum etc ${ }^{40,41}$. It was mentioned that, silver nanoparticles not only inhibit human and plant fungi but also impede indoor fungi including Penicillium brevicompactum and Aspergillus fumigates ${ }^{27,42}$.

Growth curve study. To investigate the effect of silver nanoparticles on growth curve, S. aureus was selected as a model bacterial organism, as it exhibited maximum zone of inhibition to the present silver nanoparticlesmucus matrix based dispersion sample. The growth curves of such silver based bionanocomposite treated $S$. aureus cells are shown in Fig. 9. It is seen that the growth curve of $S$. aureus was inhibited at MIC $(3.5 \mu \mathrm{g} / \mathrm{ml})$ and $2 \times \operatorname{MIC}(7.0 \mu \mathrm{g} / \mathrm{ml})$ of silver nanoparticles.

The mechanism involved in killing of bacterial cells may be explained on the basis of ROS (Reactive Oxygen Species) generation which inhibits the bacterial growth most effectively on Gram negative strains ${ }^{43,44}$.

Mechanism of action of silver nanoparticles on S. aureus cell membrane. In the present study, it was observed that silver nanoparticles could enhance protein leakage by increasing membrane permeability of S. aureus. The leakage at UV-260 and UV-280 absorbing material for the period of 90 min was monitored and the results are summarized in the Fig. 10. The absorbance at $280 \mathrm{~nm}$ was increased in $15 \mathrm{~min}$ as compared to the absorbance at $260 \mathrm{~nm}$. This suggests that silver nanoparticles alter the membrane permeability of cells which, in turn, results in the leakage of UV- 260 and UV- 280 absorbing materials.

It is the well established experimental fact that silver nanoparticles can exhibit better antimicrobial activity against Gram positive and Gram negative bacteria. In case of $E$. coli, it has been speculated that, silver nanoparticles accumulate in the cell wall and lead to cell death by formation of "pits" 45 .

Herein, we also investigated the effects of as-synthesized silver nanoparticles on leakage of proteins, reducing sugars, DNA and RNA against $S$. aureus. The results obtained are presented in Figs. 11 and 12.

Figure $11 \mathrm{~A}$ exhibits the protein leakage from $S$. aureus treated with silver nanoparticles and compared with control. From the Fig. 11A, it is evident that, after $24 \mathrm{~h}$ of incubation, control set shows $2.32 \mathrm{mg} / \mathrm{ml}$ of protein while $3 \mu \mathrm{g} / \mathrm{ml}$ and $6 \mu \mathrm{g} / \mathrm{ml}$ silver nanoparticles treated sets exhibit $3.98 \mathrm{mg} / \mathrm{ml}$ and $4.32 \mathrm{mg} / \mathrm{ml}$ of protein content, respectively. Whereas Fig. 11B exhibits the reducing sugar leakage from S. aureus treated with silver nanoparticles 


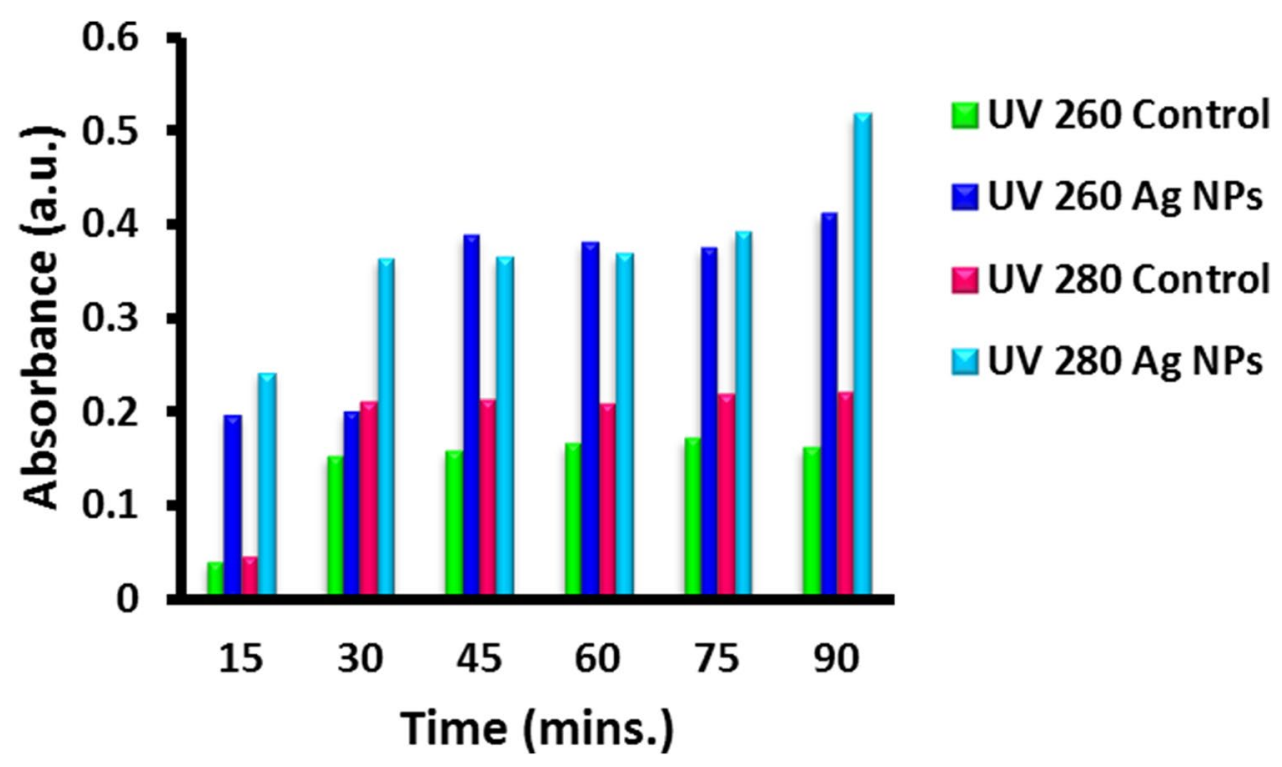

Figure 10. Leakage at $\mathrm{UV}_{260}$ and $\mathrm{UV}_{280}$ (Heipieper method) of S. aureus treated with AgNPs-SM bionanocomposites.

and compared with control. Here it has been realized that, after $24 \mathrm{~h}$ of incubation, control set shows $93 \mu \mathrm{g} / \mathrm{ml}$ of reducing sugar while $3 \mu \mathrm{g} / \mathrm{ml}$ and $6 \mu \mathrm{g} / \mathrm{ml}$ silver nanoparticles treated sets produce $247 \mu \mathrm{g} / \mathrm{ml}$ and $327 \mu \mathrm{g} / \mathrm{ml}$ of reducing sugar content, respectively.

Figure 12A indicates the DNA leakage from $S$. aureus bacterial cells treated with silver nanoparticles and compared with control. From the Fig. 12A, it can be observed that, after $24 \mathrm{~h}$ of incubation, control set shows $0.0038 \mathrm{mg} / \mathrm{ml}$ of DNA while $3 \mu \mathrm{g} / \mathrm{ml}$ and $6 \mu \mathrm{g} / \mathrm{ml}$ silver nanoparticles treated sets exhibit $0.136 \mathrm{mg} / \mathrm{ml}$ and $0.159 \mathrm{mg} / \mathrm{ml}$ of DNA content, respectively. Figure 12B exhibits the RNA leakage from $S$. aureus bacterial cells treated with silver nanoparticles and compared with control. Here, it can be noted that, after $24 \mathrm{~h}$ of incubation, control set shows $0.0015 \mathrm{mg} / \mathrm{ml}$ of RNA content while $3 \mu \mathrm{g} / \mathrm{ml}$ and $6 \mu \mathrm{g} / \mathrm{ml}$ silver nanoparticles treated sets exhibit $0.0027 \mathrm{mg} / \mathrm{ml}$ and $0.0034 \mathrm{mg} / \mathrm{ml}$ of RNA content, respectively.

During the study of membrane leakage, proteins, reducing sugars, DNA and RNA of $S$. aureus as a model organism, the silver nanoparticles may lead to formation of ROS e. g. superoxides and hydroxyl radicals, which presumably lead to disruption of the bacterial cell membrane ${ }^{46}$. It is also reported that, metal nanoparticles increase ROS through reaction of metal ions with thiol group of enzymes and exerts toxic effects related to oxidative stress ${ }^{47}$. When bacterial cell comes in contact with nanoparticles, it inhibits respiratory enzymes leading to ROS generation and thus damaging the bacterial cell ${ }^{48}$. To judge the bioactivity of biogenically generated nanomaterials, several properties of nanoparticles must be studied which are responsible for the resultant efficacy and toxicity. These properties mainly include particle size, its distribution, shape, surface charge, crystalline phase etc. It has been reported that such properties of nanoparticles can greatly influence the biological activities of the biogenically generated nanoparticles/composites ${ }^{49}$.

Cytotoxicity of Ag NPs. Along with antibacterial and antifungal activities, we have also investigated the anticancer activity of green synthesized silver nanoparticles against HeLa (cervical cancer) cells. The cytotoxicity result specified that AgNPs-SM bionanocomposite showed more than $15 \%$ inhibition of Hela cells. The present material was further selected for the dose response studies. The dose response studies were carried out at different concentrations $(100,30,10,3,1 \mu \mathrm{g} / \mathrm{ml})$ (Table 2 ).

It was noticed that all the concentrations of Ag NPs were capable of inhibition of HeLa cells in a dose-dependent manner. The inhibition activity increases with concentration in the order of $100>30>10>3>1$ (Fig. 13). The highest effective IC50 and IC90 reported for Ag NPs were $64.05 \mu \mathrm{g} / \mathrm{ml}$ and $>100$, respectively.

Cervical cancer exhibited third leading causes of cancer death after breast and lung cancers in the world, where, almost $90 \%$ of cervical deaths occur in developing countries ${ }^{50,51}$. Some researchers observed the cytotoxic effect of silver nanoparticles in HeLa cells ${ }^{52}$. It was recorded that, silver nanoparticles can lead to cell deaths which are concentration dependent. The inhibition activity increases with concentration in the order of $100>30>10>3>1 \mu \mathrm{g} / \mathrm{ml}$. The main advantage of using silver nanoparticles is that it cannot just induce apoptosis but also can recognize the cancer cells ${ }^{53}$. It was witnessed that the combination of anticancer agents with nanoparticles shows significant inhibition in cell viability and proliferation, for instance, combination therapy of CPT and AgNPs has shown significant inhibition in cell viability and proliferation of HeLa cells by modulating cellular signaling molecules associated with cell survival, cytotoxicity, and apoptosis ${ }^{50}$. Further, the synthesized silver nanoparticles with other reported anticancer agents and their derivatives can certainly provide a beneficial effect in the treatment of different types of cancers. It was also noted that, biologically synthesized silver nanoparticles lead to cell death very effectively. Chitosan coated silver nanoparticles exhibited increased 


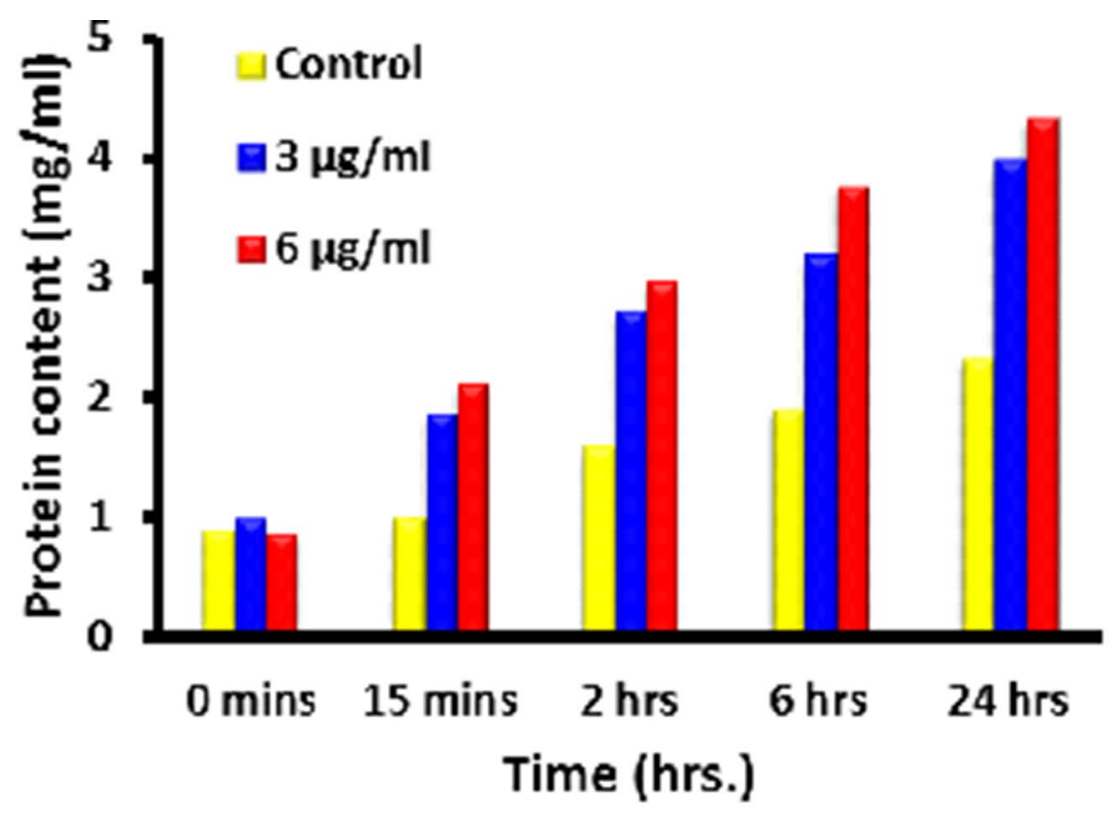

A 


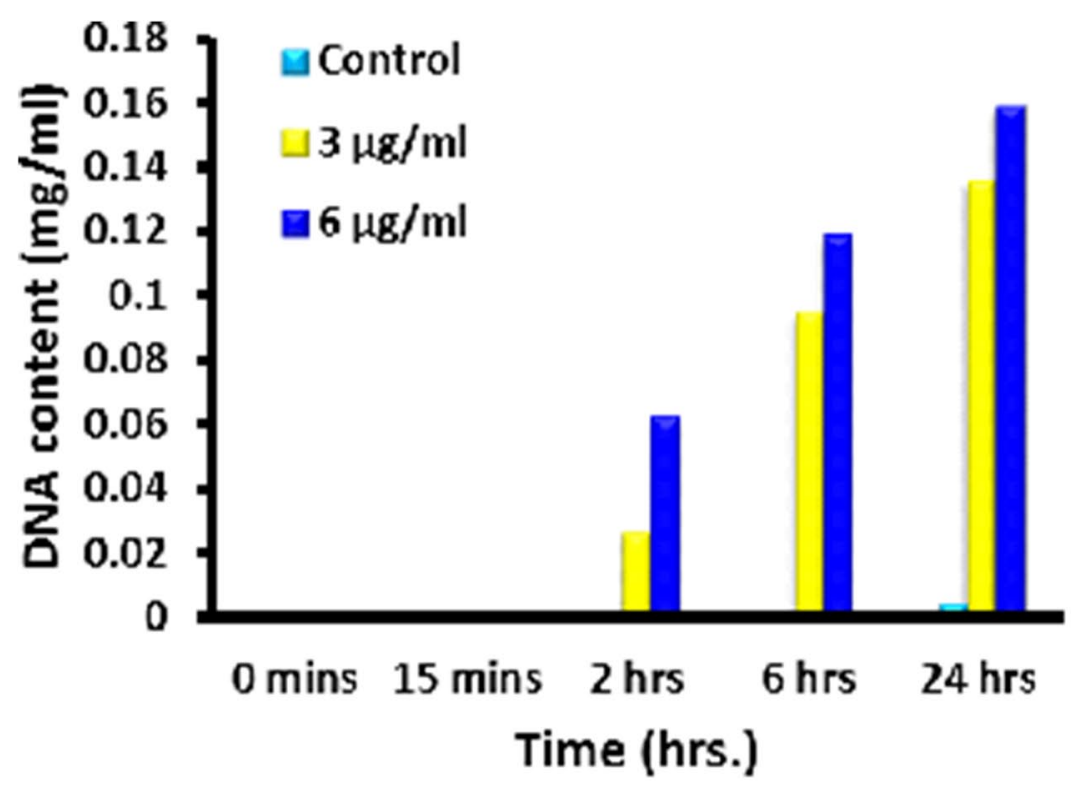

A

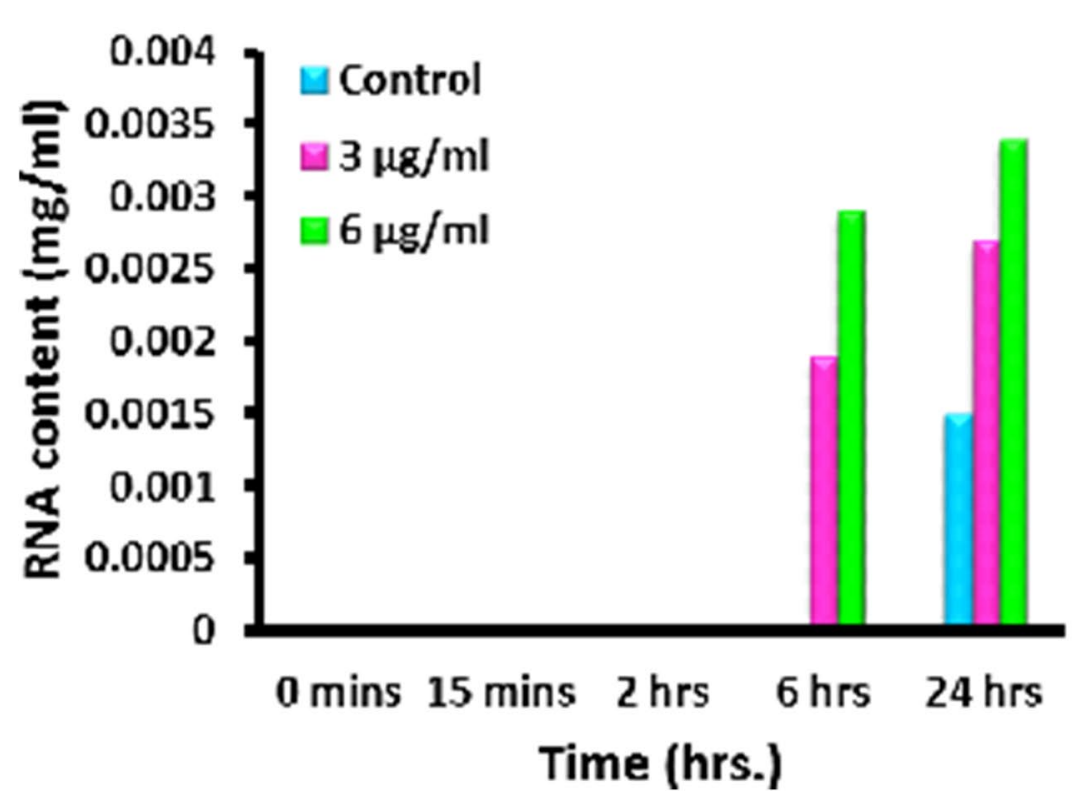

Figure 12. Leakage of (A) DNA and (B) RNA from S. aureus after treatment with AgNPs-SM bionanocomposites.

\begin{tabular}{|l|l|l|l|l|l|l|l|l|}
\hline Concentration of Ag NPs & $\mathbf{0}$ & $\mathbf{1}$ & $\mathbf{3}$ & $\mathbf{1 0}$ & $\mathbf{3 0}$ & $\mathbf{1 0 0}$ & IC50 & IC90 \\
\hline Percent inhibition & 0.00 & 15.59 & 17.73 & 19.85 & 39.26 & 58.65 & 64.05 & $>100$ \\
\hline
\end{tabular}

Table 2. IC50 and IC90 value of Ag NPs.

$-20{ }^{\circ} \mathrm{C}$ until being used for further experiments ${ }^{57}$. After the extraction was over, the snails were freed back to their original natural habitat.

Estimation of proteins, free amino acids and sodium dodecyl sulfate-polyacrylamide gel electrophoresis (SDS-PAGE) of snail mucus. Total proteins were estimated from the mucus sample by the Lowry et al.method ${ }^{58}$. Total free amino acids were estimated by the Ninhydrin method ${ }^{59}$. SDS-PAGE of isolated 


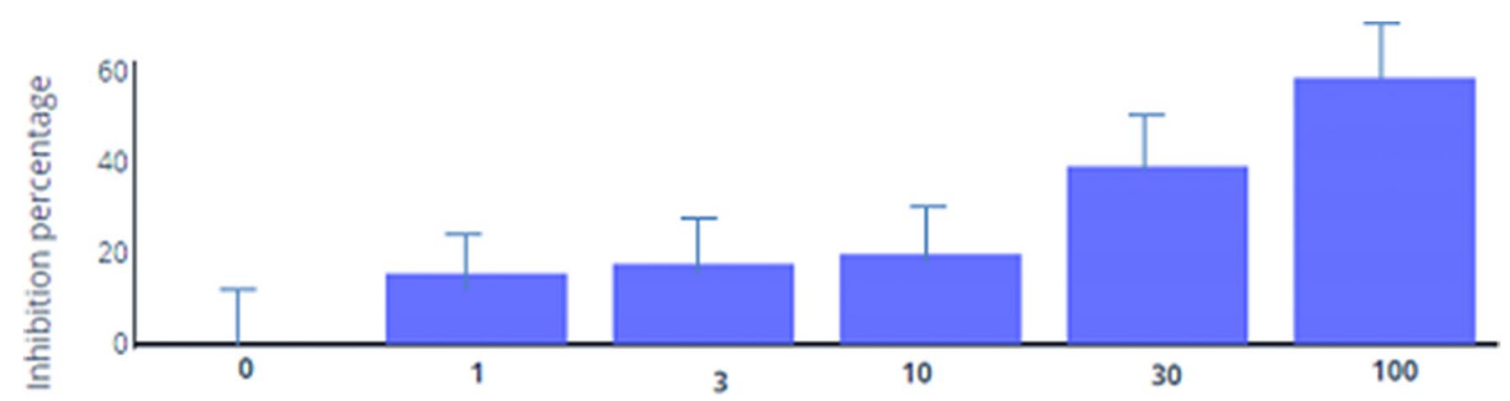

Ag NPS Concentration

Figure 13. Dose response studies of AgNPs-SM bionanocomposite against HeLa cells.

mucus sample was carried out on a vertical gel electrophoresis system (Hoffer). Proteins were electrophoresed on $12 \%$ separating gel overlaid with $5 \%$ stacking gel. The protein bands of mucus were compared with standard protein marker (GeNei) with broad range molecular weights ( 3.5 to $205 \mathrm{kDa}$ ). The protein profile was visualized, documented and preserved by the modified method ${ }^{60}$. All the experiments including estimation of proteins, total amino acids etc. were replicated thrice.

Synthesis of silver nanoparticles using A. fulica snail mucus. The biocompatible silver nanoparticles were synthesized within mucus matrix of $A$. fulica. In a typical procedure, diluted $(1: 9 \mathrm{v} / \mathrm{v}) A$. fulica mucus $(100 \mathrm{ml})$ was mixed with $284 \mathrm{mM}$ ascorbic acid and $66 \mathrm{mM}$ polyvinyl pyrrolidone and $35 \mathrm{mM} \mathrm{AgNO}$. The initial $\mathrm{pH}$ of the diluted mucus was around 7 but, after the addition of ascorbic acid and polyvinyl pyrrolidone, $\mathrm{pH}$ of the resultant mixture was found to be changed to 4 . The whole mixture was stirred at $250 \mathrm{rpm}$ for $45 \mathrm{~min}$ and exposed to sunlight to sharpen the color of the dispersion mixture from gray to brown within short time period of 2-5 min implying the formation of silver nanoparticles ${ }^{61}$. This distinctive change in colour can be attributed to size and shape dependent Surface Plasmon Resonance of Ag nanoparticles in solution when exposed to visible $\operatorname{light}^{13}$. After visually noticing such a change in the color of the dispersion mixture, the powder product formed was collected by centrifugation at 12,000 RPM for $10 \mathrm{~min}$ and washed several times with double distilled water until its $\mathrm{pH}$ becomes neutral. Silver nanoparticles-snail mucus nanocomposite powder (referred hereafter as AgNPs-SM) was finally obtained by drying the resultant semi-solid mass in lamellar air flow at room temperature for 1 day. For the sake of comparison, various combinative admixtures corresponding to individual reactants namely snail mucus, silver nitrate, PVP and ascorbic acid were also prepared.

Physico-chemical characterization of the resultant nanoparticulate composites. A. fulica mucus and typical AgNPs-SM samples were separately suspended in sterile distilled water for performing UVvisible spectroscopy study. The spectra were recorded by using UV visible NIR spectrophotometer (JASCO $\mathrm{V}-770$ ) in the wavelength range of $200-600 \mathrm{~nm}$ against distilled water as baseline solution by using optiglass cuvette with path length of $10 \mathrm{~mm}$ and bandwidth of $1.0 \mathrm{~nm}$. Surface morphological features and the pertinent elemental composition of AgNPs-SM were determined by acquiring Field Emission Scanning Electron Microscopy (FE-SEM) images using FEI, Nova NanoSEM NPEP303. For this purpose, the synthesized AgNPs-SM powder was directly sprinkled on the conducting carbon tape attached to aluminum stub. It was then coated with very thin conducting gold film to minimize the effects arising due to charging. Silver nanoparticles-snail mucus nanocomposite powder (AgNPs-SM) obtained by drying the resultant semi-solid mass in lamellar air flow at room temperature was used for the structural analysis by X-ray diffractometry (XRD). XRD pattern of the dried AgNPs-SM powder sample was recorded with X-ray diffractometer (Bruker, D8, ADVANCE, Germany) with $\mathrm{Ni}$-filtered $\mathrm{CuK}_{\alpha}$ radiation $\left(\lambda=1.54 \AA\right.$ ) operating in the reflection mode at a scan speed of $4^{\circ} / \mathrm{min}$. Information about the functional group bonding between silver nanoparticles and the snail mucus matrix was obtained using the Fourier Transform Infra-Red (FTIR) spectroscopy (JASCO FT/IR-6100 FTIR spectrophotometer) recorded in the attenuated total reflection (ATR) mode with an ATR Pro One unit for the powder sample. Both for XRD and FTIR investigations, dried as-prepared powder samples were directly used without any further processing.

Antimicrobial activity of silver nanoparticles in snail mucus matrix. The screening of antimicrobial activity of the resultant silver nanoparticles in mucus matrix was carried out by the agar well diffusion method using nutrient agar (NA) medium. The organisms studied in the present research namely E. coli NCIM 2065, S. aureus NCIM 5021, K. pneumoniae NCIM 2957 and P. aeruginosa ATCC 9027 were procured from the National Chemical Laboratory (NCL, Pune). The bacterial inocula were prepared from the colonies of $24 \mathrm{~h}$ old culture on nutrient agar medium. The inoculum was adjusted to final concentration of approximately $10^{6} \mathrm{CFU} /$ $\mathrm{ml}$ for the bacteria. Silver nanoparticles-snail mucus dispersion (prepared by subjecting to ultrasonication for $10 \mathrm{~min}$ in sterile distilled water) was added in the wells of the test media which were previously inoculated with each test strain. Plates were incubated at $37{ }^{\circ} \mathrm{C}$ and inhibition zones were measured after $24 \mathrm{~h}$ of incubation ${ }^{62}$. MIC (Minimum Inhibitory Concentration) represents the lowest concentration required to inhibit the growth of micro-organisms. It was characteristically determined by serially diluting silver nanoparticles in the concentra- 
tions of 2, 2.5, 3, 3.5, 4 and $4.5 \mu \mathrm{g} / \mathrm{ml}$. Micro-organisms were grown in Mueller Hinton broth at $37^{\circ} \mathrm{C}$. All assays were carried out for three times and the control test was performed with the mucus ${ }^{63}$. The MBC/MFC values of the silver nanoparticles in mucus matrix were determined by taking samples from tubes of the MIC assay which were subsequently sub-cultured on freshly prepared nutrient agar plates or potato dextrose agar plates, and incubated at $37^{\circ} \mathrm{C}$ or $28^{\circ} \mathrm{C}$ for $48 \mathrm{~h}$, respectively. The $\mathrm{MBC} / \mathrm{MFC}$ was taken as the concentration of silver nanoparticles that did not show any growth on a new set of agar plates ${ }^{64}$.

Determining the growth curves of bacterial cells. To examine the growth curves, bacterial cell concentration in Muller-Hinton broth was adjusted to $10^{6} \mathrm{CFU} / \mathrm{ml}$ and exposed to silver nanoparticulate dispersion at different concentrations viz., 1/2 MIC, MIC and 2 MIC. Each culture was incubated in a shaking incubator at $37^{\circ} \mathrm{C}$ for $24 \mathrm{~h}$. Growth curves of bacterial cell cultures were attained through repeated measurements of the optical density (OD) at $600 \mathrm{~nm}$.

Mode of action of silver nanoparticles on bacterial cells. MIC of silver nanoparticles was used to judge the mode of action on bacteria. For this purpose, the concentrations of bacteria were adjusted to $10^{6} \mathrm{CFU} /$ $\mathrm{ml}$ and were exposed to silver nanoparticulate composites for $6 \mathrm{~h}$. One $\mathrm{ml}$ of sample was withdrawn from each set and the concentration of reducing sugars, proteins, DNA and RNA was determined. The method of Heipieper was also followed to determine the leakage at UV260 and UV280 absorbing material ${ }^{65}$.

Cytotoxicity assay. HeLa (cervical cancer) cell lines were obtained from the National Center for Cell Science (NCCS), Pune and maintained in T25 flasks with 10\% (v/v) fetal bovine serum (FBS) containing Dulbecco's Modified Eagle Medium (DMEM). Cells were maintained at $37{ }^{\circ} \mathrm{C}$ under $5 \% \mathrm{CO}_{2}$ and $95 \%$ air in a humidified atmosphere.

The suspensions of biologically synthesized silver nanoparticles-snail mucus composite were prepared by ultasonicating typical sample powder for $10 \mathrm{~min}$ in sterile DMSO (1\%) and were subsequently tested for their cytotoxicity by using modified MTT [(3-(4,5-dimethylthiazol-2-yl)-2,5-diphenyltetrazolium bromide)] assay as described previously ${ }^{66}$. In brief, cells were seeded at the density of $1 \times 10^{5}$ cells $/ \mathrm{ml}$ in 96 well plates. The plates were incubated overnight in $\mathrm{CO}_{2}$ incubator $\left(37^{\circ} \mathrm{C}\right.$ under $5 \% \mathrm{CO}_{2}$ and $95 \%$ air in a humidified atmosphere). Next day, cells were treated with synthesized nanoparticles at single concentration $(10 \mu \mathrm{g} / \mathrm{ml})$ and incubated for further $48 \mathrm{~h}$. Paclitaxel was used as positive control. After incubation, cell medium was replaced with MTT $(0.5 \mathrm{mg} / \mathrm{mg})$ - Phosphate Buffered Saline (PBS) medium and incubated for $2-4 \mathrm{~h}$ to form the reduced MTT or Formazan crystals. This reduced MTT or Formazan crystals were solubilized by addition of $100 \mu \mathrm{l}$ of SDS-DMF (sodium dodecyl sulfate-N, N-dimethylformamide) (20\% SDS in 50\% DMF). The optical density was read on a microplate reader (Spectramax plus 384 plate reader, Molecular Devices Inc) at $570 \mathrm{~nm}$ filter against blank prepared cell free wells. Absorbance given by the cells treated with the vehicle alone was taken as $100 \%$ cell growth. $\mathrm{IC}_{50}$ and MIC values were calculated from the graphs, using Origin Pro software. The percent cytotoxicity in the presence of test fractions was calculated by the following formula:

$$
\begin{aligned}
\text { Percent cytotoxicity }= & {[\text { (average absorbance of control-absorbance of a compound }) } \\
& /(\text { absorbance of control-absorbance of blank })] \times 100
\end{aligned}
$$

where DMSO treated cells formed the control and culture medium without cells was treated as blank.

\section{Conclusions}

We have offered ecofriendly biogenic synthesis of silver nanoparticles involving unique biomaterial i. e. naturally secreted mucus of terrestrial snail Achatina fulica. Apart from utility of mucus in bio-reduction and biostabilization steps in the synthesis of AgNPs, the possibility of developing antimicrobial skin-care products has been the main motivational aspect of our research leveraging well-known antimicrobial activity of AgNPs and well-documented benefits of snail mucus in skin-care. Towards this end, we have ascertained antimicrobial performance of the resultant AgNPs-SM composite samples against different pathogens. Specifically, we have observed high antimicrobial activity against deadly pathogen Pseudomonas aeruginosa which tends to become resistant to various antibiotics in the hospital settings. Most importantly, in a pilot attempt, silver nanoparticles in biocompatible mucus matrix exhibited anti-cancer activity against HeLa (cervical cancer) cell lines. From the standpoint of future therapeutic applications based on our primary investigations, we put forward the possibility of realizing AGNPs-SM based topical cream/gel for effective acne treatment as well as for rapid wound healing without leaving scar on the affected skin. Such an idea can probably be extended to formulate anti-cancer cream/ gel for specific topical application.

Received: 24 December 2020; Accepted: 8 June 2021

Published online: 22 June 2021

\section{References}

1. Akhtar, M. S., Panwar, J. \& Yun, Y. S. Biogenic Synthesis of Metallic Nanoparticles by Plant Extracts. ACS Sustain. Chem. Eng. 1, 591-602 (2013).

2. Elsupikhe, R. F., Shameli, K., Ahmad, M. B., Ibrahim, N. A. \& Zainudin, N. Green sonochemical synthesis of silver nanoparticles at varying concentrations of k-carrageenan. Nanoscale Res. Lett. 10, 302. https://doi.org/10.1186/s11671-015-0916-1 (2015). 
3. Gurunathan, S. et al. Biosynthesis, purification and characterization of silver nanoparticles using Escherichia coli. Colloids Surf. B Biointer. 74, 328-335 (2009).

4. Gurunathan, S., Han, J. W., Kim, E. S., Park, J. H. \& Kim, J. H. Reduction of graphene oxide by resveratrol: A novel and simple biological method for the synthesis of an effective anticancer nanotherapeutic molecule. Int. J. Nanomed. 10, 2951-2969 (2015).

5. Kumar, D. R. et al. Biological synthesis of metallic nanoparticles: plants, animals and microbial aspects. Nanotechnol. Environ. Engg. 2(1), 18 (2017).

6. Neutra, M. R. \& Forstner, J. F. Gastrointestinal mucus: synthesis, secretion and function, in Physiology of the Gastrointestinal Tract, 2nd edition Raven Press, New York, NY, pp 975-1009 (1987).

7. Allen, J. A. \& Morgan, R. E. The functional morphology of Atlantic deep water species of the families Cuspidarlidae and Poromyidae (Bivalive): an analysis of the evolution of the septibranch condition. Phil. Trans. R. Soc. Lond. B. 294, 413-546 (1981).

8. Claudio, T. et al. Helix Complex snail mucus exhibits pro-survival, proliferative and pro-migration effects on mammalian fibroblasts. Sci. Rep. 8, 17665. https://doi.org/10.1038/s41598-018-35816-3 (2018).

9. Prabhu, S. \& Poulose, E. K. Silver nanoparticles: mechanism of antimicrobial action, synthesis, medical applications and toxicity effects. Int. Nano Lett. 2(32), 1-10. https://doi.org/10.1186/2228-5326-2-32 (2012).

10. Zhang, X. F., Liu, Z. G., Shen, W. \& Gurunathan, S. Silver nanoparticles: Synthesis characterization, properties, applications and therapeutic approaches. Int. J. Mol. Sci. 17(9), 1534. https://doi.org/10.3390/ijms17091534 (2016).

11. Saravanan, M., Ramachandran, B. \& Barabadi, H. The prevalence and drug resistance pattern of extended spectrum $\beta$-lactamases (ESBLs) producing Enterobacteriaceae in Africa. Microb. Pathog. 114, 180-192 (2017).

12. Qureshi, N. et al. Innovative biofilm inhibition and anti-microbial behavior of molybdenum sulfide nanostructures generated by microwave-assisted solvothermal route. Appl. Nanosci. 5, 331-341. https://doi.org/10.1007/s13204-014-0322-5 (2015).

13. Mane, P. et al. Designing Ecofriendly Bionanocomposite Assembly with Improved Antimicrobial and Potent on-site Zika Virus Vector Larvicidal Activities with its Mode of Action. Sci. Rep. 7, 15531. https://doi.org/10.1038/s41598-017-15537-9 (2017).

14. Roe, D., Karandikar, B., Bonn-Savage, N., Gibbins, B. \& Roullet, J.-B. Antimicrobial surface functionalization of plastic catheters by silver nanoparticles. Antimicrob. Chemother. 61(4), 869-876 (2008).

15. Clasen, T. F., Brown, J., Collins, S., Santura, O. \& Cairncross, S. Reducing diarrhea through the use of household-based ceramic water filters: a randomized, controlled trial in rural Bolivia. Am. J. Trop. Med. Hyg. 70(6), 651-657 (2004).

16. Barabadi, H. et al. Penicillium family as emerging nanofactory for biosynthesis of green nanomaterials: a journey into the world of microorganisms. J. Cluster Sci. 30(4), 843-856 (2019).

17. Khatua, A. et al. Phytosynthesis, characterization and fungicidal potential of emerging gold nanoparticles using Pongamia pinnata leave extract: a novel approach in nanoparticle synthesis. J. Cluster Sci. 31(1), 125-131 (2020).

18. Esposito, S. \& Simone, G. D. Update on the main MDR pathogens: prevalence and treatment options. Infez Med. 25(4), 301-310 (2017).

19. Barabadi, H. et al. Nanobiotechnology as an emerging approach to combat malaria: a systematic review. Nanomed. Nanotechnol. Biology Med. 18, 221-233 (2019).

20. Estaban, M. A. An overview of the immunological defenses in fish skin. ISRN Immunol. 1, 1-29 (2012).

21. Patel, D. M. \& Brinchmann, M. F. Skin mucus proteins of lumpacker (Cyclopteruslumpus). Biochem. Biophy. Rep. 9, 217-225 (2017).

22. Nigan, A. K., Kumari, U., Nigam, G. D., Mittal, S. \& Kumar, A. K. Comparative biochemical analysis of skin mucus secretions from certain freshwater teleosts. Res. Environ. Life Sci. 5(4), 218-222 (2012).

23. Stabili, L., Schirosi, R., Parisi, M. G., Piraino, S. \& Cammarata, M. The mucus of Actinia equine (Anthozoa, Cnidaria): An unexplored resource for potential applicative purposes. Mar. Drugs 13, 5276-5296 (2015).

24. Birkemo, G. A., Luders, T., Anderson, O., Nes, I. F. \& Nissan-Meyyer, J. Hipposin, a histone derived antimicrobial peptide in Atlantic halibut (Hippoglossus hippopglossus). Biochim. Biophys. Acta. 1646, 207-215 (2003).

25. Uthayakumar, V., Ramasubramanian, V., Senthilkumar, D., Priyadarisini, V.B. \& Harikrishanan, R. Biochemical characterization, antimicrobial and hemolytic studies on skin mucus of freshwater spiny eel Mastacembelus armatus. Asian Pac. J. Trop. Biomed. s863-s869 (2012).

26. Gentili, V. et al. Helix Complex snail mucus as a potential technology against O3 induced skin damage. PLoS ONE 15(2), e0229613. https://doi.org/10.1371/journal.pone.0229613 (2020).

27. Harti, A.S., Murharyati, A., Suliesetyawati, D. \& Oktariani, M. The Effectiveness of snail mucus (Achatina fulica) and chitosan toward limfosit proliferation in vitro. Asian J. Pharmaceutic. Clinical Res. 11 (2018). https://doi.org/10.22159/ajpcr.2018.v11s3. 30041.

28. Tran, M. T., Le, V. T., Bui, H. V., Pham, V. B. \& Vu, Q. T. The Effect of Polyvinylpyrrolidone on the Optical Properties of the NiDoped ZnS Nanocrystalline Thin Films Synthesized by Chemical Method. J. Nanomat. 2012, 1-8. https://doi.org/10.1155/2012/ 528047 (2012).

29. Lawendel, J. S. Ultra-violet absorption spectra of L-ascorbic acid in aqueous solutions. Nature 180, 434-435 (1957).

30. Zamzow, J. P. \& Losey, G. S. Ultraviolet radiation absorbance by coral reef fish mucus: photo-reaction and visual communication. Envir. Biol. Fishes. 63, 41-47 (2002).

31. Douglas, R.H. \& Hawryshyn, C.W. Behavioral studies of fish vision: an analysis of visual capabilities, In: The visual system of fish, London, Chapman and Hall. 373-418 (1990).

32. Tayo, A, Bukola, Salaam, A. \& Ajibade, A. Green synthesis of silver nanoparticle using Oscillatoria sp. extract, its antibacterial, antibiofilm potential and cytotoxicity activity. Heliyon. 5(10), e02502 (2019).

33. Skingsley, D. R., White, A. J. \& Weston, A. Analysis of Pulmonate mucus by infrared spectroscopy. J. Moll. Stud. 66, 363-371 (2000).

34. Shahverdi, A. R., Fakhimi, A., Shahverdi, H. R. \& Minaian, S. Synthesis and effect of silver nanoparticles on the antibacterial activity of different antibiotics against Staphylococcus aureus and Escherichia coli. Nanomed. 3, 168-171 (2007).

35. Saravanan, M. et al. Emerging antineoplastic biogenic gold nanomaterials for breast cancer therapeutics: a systematic review. Internatl. J. Nanomed. 15, 3577 (2020).

36. Jennifer, G. et al. Biomolecules from Snail mucus (Helix aspersa) conjugate Gold nanoparticles, exhibiting potential wound healing and anti-inflammatory activity. Soft Matter https://doi.org/10.1039/D0SM01638A (2020).

37. Kim, K. J. et al. Antifungal effect of silver nanoparticles on dermatophytes. J. Microbial. Biotechnol. 18, 1482-1484 (2008).

38. Qureshi, N. et al. Nanoscale $\mathrm{Mo}-\mathrm{MoO}_{3}$ Entrapped in Engineering Thermoplastic: Inorganic Pathway to Bactericidal and Fungicidal Action. IEEE Trans. NanoBiosci. 15, 258-264 (2016).

39. Esteban-Tejeda, L., Malpartida, F., Esteban-Cubillo, A., Pecharroman, C. \& Moya, J. S. The antibacterial and antifungal activity of a soda lime glass coating silver nanoparticles. Nanotech. 20, 085103 (2009).

40. Jain, J. et al. Silver nanoparticles in therapeutics: Development of an antimicrobial gel formulation for topical use. Mol. Pharma. 6, 1388-1401 (2009).

41. Gajbhiye, M., Kesharwani, J., Ingale, A., Gade, A. \& Rai, M. Fungus-mediated synthesis of silver nanoparticles and their activity against pathogenic fungi in combination with fluconazole. Nanomed. 5, 382-386 (2009).

42. Ogar, A., Tylko, G. \& Turnau, K. Antifungal properties of silver nanoparticles against indoor mould growth. Sci. Total Environ. 521, 305-314 (2015).

43. Nair, S. et al. Role of size scale of $\mathrm{ZnO}$ nanoparticles and microparticles on toxicity toward bacteria and osteoblast cancer cells. J. Mater. Sci: Mater. Med. 20(Suppl. 1), S235-S241 (2009). 
44. Alshami, J. \& Alharbi, A. E. Antimicrobial activity of Hibiscus sabdariffa extract against uropathogenic strains isolated from recurrent urinary tract infections. Asian Pac. J. Trop. Dis. 4, 317-322 (2014).

45. Sondi, I. \& Salopek -Sondi, B. Silver nanoparticles as antimicrobial agent: A case study on E. coli as a model for Gram-negative bacteria. J. Colloid Interface Sci. 275, 177-182 (2004).

46. Surendra, T. V., Roopan, S, M., Al-Dhabi, N. A., Arasu, M. V., Sarkar, G. \& Suthindhiran. K. Vegetable peel waste for the production of $\mathrm{ZnO}$ nanoparticles and its toxicological Efficiency, Antifungal, Hemolytic and Antibacterial Activities. Nanoscale Res. Lett. 11 (1), 546 (2016). https://doi.org/10.1186/s11671-016-1750-9

47. Wahab, R., Kaushik, N.K., Kaushik, N., Choi, E.H., Umar, A. \& Dwivedi S, et al. ZnO nanoparticles induces cell death in malignant human T98G gliomas, KB and non-malignant HEK cells. J. Biomed Nanotechnol. 9, 1181-1189(2013).

48. Dwivedi, S. et al. Reactive oxygen species mediated bacterial biofilm inhibition via Zinc Oxide Nanoparticles and their statistical determination. PLoS ONE 9(11), el11289. https://doi.org/10.1371/journal.pone.0111289 (2014).

49. Saravanan, M., Barabadi, H., Ramachandran, B., Venkatraman, G., \& Ponmurugan, K. Emerging plant-based anti-cancer green nanomaterials in present scenario. Comprehensive Anal. Chem. 87, 291-318 (2019). Elsevier.

50. Yuan, Y. G., Zhang, S., Hwang, J. Y. \& Kong, I. K. Silver nanoparticles potentiates cytotoxicity and apoptotic potential of camptothecin in human cervical cancer cells. Oxidative med. cellular longi. https://doi.org/10.1155/2018/6121328 (2018).

51. Ferlay, J. et al. Cancer incidence and mortality worldwide: sources, methods and major patterns in GLOBOCAN 2012. Internatl. J. Cancer. 136(5), E359-E386 (2015).

52. Miura, N. \& Shinohara, Y. Cytotoxic effect and apoptosis induction by silver nanoparticles in HeLa cells. Biochem. Biophys. Res. commun. 390(3), 733-737 (2009).

53. Gopinath, P., Gogoi, S. K., Chattopadhyay, A. \& Ghosh, S. S. Implications of silver nanoparticle induced cell apoptosis for in vitro gene therapy. Nanotech. 19, 075104 (2008).

54. Boca, S. C. et al. Chitosan-coated triangular silver nanoparticles as a novel class of biocompatible, highly effective photothermal transducers for in vitro cancer cell therapy. Cancer Lett. 311, 131-140 (2011).

55. Ortega, F. G. et al. Study of antitumor activity in breast cell lines using silver nanoparticles produced by yeast. Int. J. Nanomed. 10, 2021-2031 (2015).

56. Foldbjerg, R., Dang, D. A. \& Autrup, H. Cytotoxicity and genotoxicity of silver nanoparticles in the human lung cancer cell line, A549. Arch Toxicol. 85, 743-750. https://doi.org/10.1007/s00204-010-0545-5 (2011).

57. Sallam, A. A. A., EI-Massry, S. A. \& Nasr, I. N. Chemical analysis of mucus from certain land snails under Egyptian conditions. Arch. Phytopath Plant Prot. 42, 874-881 (2009).

58. Lowry, O. H., Rosenbrough, N. J., Fair, A. L. \& Randall, R. J. Protein measurement with the Folin-Phenol reagent. J. Biol. Chem. 193, 265-275 (1951).

59. Moore, S. \& Stein, W. H. In: Methods in Enzymol. Academic Press, New York 468 (1948).

60. Laemmli, U. K. Cleavage of structure proteins during the assembly of the head of the bacteriophage T4. Nature 227(5259), 680-685 (1970).

61. Maria, L. C. S. et al. Synthesis and characterization of silver nanoparticles impregnated into bacterial cellulose. Mater. Lett. 63(9-10), 797-799 (2009).

62. Irobi, O. N., Moo-Young, M., Anderson, W. A. \& Daromola, S. O. Antimicrobial activity of the bark of Bridelia ferrugines (Euohirbiaceae). Intr. J. Pharmaco. 34, 87-90 (1994).

63. Akinpelu, D. A. \& Kolawale, D. A. Phytochemical and antimicrobial activity of leaf extract of Piliostigma thonningii (Schum). Sci. Focus J. 7, 64-70 (2004).

64. Spencer, L. R. \& Spencer, J. F. T. Phytochemical and antimicrobial activity of leaf extract of Piliostigma thonningii (Schum) 325-327 (Human Press Inc., 2004).

65. Heipieper, H. J., Diefenbach, R. \& Kewelol, H. Conversion of Cis unsaturated fatty acids to Trans, a possible mechanism for the protection of phenol degrading Pseudomonas putida P8 from substrate toxicity. Appl. Environ. Microbiol. 58, 1847-1852 (1992).

66. Choudhari, M. K., Haghniaz, R. J., Rajwade, M. \& J. M., \& Kishore M. Paknikar, K. M. ,. Anticancer Activity of Indian Stingless Bee Propolis: An In Vitro Study. Evidence-Based Compl. \& Altr. Med. 2013, 1-10. https://doi.org/10.1155/2013/928280 (2013).

\section{Acknowledgements}

The authors would like to express their sincere thanks and gratitude to the Chairman and Trustees, JTSSPM, Junnar and the Principal, Shri Shiv Chhatrapati College, Junnar for providing all the laboratory facilities. The authors extend their appreciation to the Deanship of Scientific Research at King Saud University for funding this work through Research Grant No (RG-1440-093).

\section{Author contributions}

R.D.C. and D.P.A. devised the broad experimental framework; R.D.C. directed the research work; P.C.M., S.A.R.S., and D.D.K. conducted the experiments; A.F. and E.A.A. provided useful comments on the manuscript; R.D.C., D.P.A., A.M.A. wrote the manuscript with the assistance of P.C.M. M.D.S. All the authors approved the manuscript after careful reading.

\section{Competing interests}

The authors declare no competing interests.

\section{Additional information}

Supplementary Information The online version contains supplementary material available at https://doi.org/ 10.1038/s41598-021-92478-4.

Correspondence and requests for materials should be addressed to A.M.A., D.P.A. or R.D.C.

Reprints and permissions information is available at www.nature.com/reprints.

Publisher's note Springer Nature remains neutral with regard to jurisdictional claims in published maps and institutional affiliations. 
(c) (i) Open Access This article is licensed under a Creative Commons Attribution 4.0 International cc) License, which permits use, sharing, adaptation, distribution and reproduction in any medium or format, as long as you give appropriate credit to the original author(s) and the source, provide a link to the Creative Commons licence, and indicate if changes were made. The images or other third party material in this article are included in the article's Creative Commons licence, unless indicated otherwise in a credit line to the material. If material is not included in the article's Creative Commons licence and your intended use is not permitted by statutory regulation or exceeds the permitted use, you will need to obtain permission directly from the copyright holder. To view a copy of this licence, visit http://creativecommons.org/licenses/by/4.0/.

(C) The Author(s) 2021 